\title{
NUTRIENT CONCENTRATIONS IN POTATO STEM, PETIOLE AND LEAFLET IN RESPONSE TO POTASSIUM FERTILIZER
}

\author{
Roberto dos Anjos Reis Jr. ${ }^{1 *}$; Pedro Henrique Monnerat ${ }^{2}$ \\ ${ }^{1}$ DCS/UFLA, C.P. 37 - CEP: $37200-000$ - Lavras, MG. \\ 2 CCTA/UENF, CEP: 28015-620 - Campos dos Goytacazes, RJ. \\ *Corresponding author <reisjr@ufla.br>
}

\begin{abstract}
Chemical composition of potato stem, petiole and leaflet were evaluated in response to the application of $\mathrm{K}$ fertilizer. Potassium was applied at six different rates $\left(0,60,120,240,480\right.$ and $960 \mathrm{~kg} \mathrm{ha}^{-1}$ of $\mathrm{K}_{2} \mathrm{O}$ ), as $\mathrm{K}_{2} \mathrm{SO}_{4}$ and was placed in the furrow during planting. Two plants per plot were sampled 48 days after plant emergence to evaluate N, P, K, Ca, Mg, S, Cu, Mn and Zn concentrations in stems, petioles and leaflets of the youngest fully expanded leaf. It is recommended using potato petioles to evaluate the $\mathrm{N}, \mathrm{P}, \mathrm{K}, \mathrm{Ca}, \mathrm{Mg}$ and Cu status and using potato leaflet to evaluate the $\mathrm{S}, \mathrm{Mn}$ and $\mathrm{Zn}$ status. The stem was not a good indicator of $\mathrm{S}$ nutritional status. Petiole N, $\mathrm{P}$ and $\mathrm{Cu}$ concentrations associated with the maximum tuber yield $\left(30.5 \mathrm{t} \mathrm{ha}^{-1}\right.$, with $353.4 \mathrm{~kg} \mathrm{ha}^{-1}$ of $\mathrm{K}_{2} \mathrm{O}$ ) were $25.9 \mathrm{~g} \mathrm{~kg}^{-1}, 1.4 \mathrm{~g} \mathrm{~kg}^{-1}$ and $9.7 \mathrm{mg} \mathrm{kg}^{-1}$, respectively, while, the leaflet $\mathrm{S}, \mathrm{Mn}$ and $\mathrm{Zn}$ concentrations associated with the maximum tuber yield were $4.0 \mathrm{~g} \mathrm{~kg}^{-1}, 155.2 \mathrm{mg} \mathrm{kg}^{-1}$ and $59.4 \mathrm{mg} \mathrm{kg}^{-1}$, respectively. This information should be used to build data banks of adequate nutrient concentration at different portions of potato plant and like this, to aid the nutrient diagnosis in potato crops.

Key words: nutrient, nutritional monitoring, potato
\end{abstract}

\section{TEORES DE NUTRIENTES NO CAULE, PECÍOLO E LIMBO DA BATATEIRA EM FUNÇÃO DA ADUBAÇÃO POTÁSSICA}

\begin{abstract}
RESUMO: Para avaliar a composição mineral em órgãos da batateira em função da adubação potássica, foi realizado experimento com doses de potássio $\left(0,60,120,240,480\right.$ e $960 \mathrm{~kg} \mathrm{ha}^{-1}$ de $\left.\mathrm{K}_{2} \mathrm{O}\right)$ delineado em blocos casualizados com quatro repetições. Duas plantas por parcela foram amostradas aos 48 dias após emergência das plantas para avaliar teores de N, P, K, Ca, Mg, S, Cu, Mn e Zn no caule, pecíolo e limbo da folha recém madura. Recomenda-se utilizar o pecíolo da batateira para avaliar o status de N, P, K, Ca, Mg e Cu e utilizar o limbo da batateira para avaliar o status de S, Mn e Zn. O caule não foi um bom indicador do estado nutricional em relação ao $\mathrm{S}$. A aplicação de $353,4 \mathrm{~kg} \mathrm{ha}^{-1}$ de $\mathrm{K}_{2} \mathrm{O}$ proporcionou a máxima produtividade de tubérculos (30,5 t ha $\left.{ }^{-1}\right)$ e teores de N, P e Cu no pecíolo iguais a $25,9 \mathrm{~g} \mathrm{~kg}^{-1}, 1,4 \mathrm{~g} \mathrm{~kg}^{-1}$ e 9,7 mg kg $\mathrm{mg}^{-1}$, respectivamente, e teores de S, Mn e Zn no limbo iguais a 4,0 g kg-1, 155,2 mg kg-1 e 59,4 mg kg-1, respectivamente. Estas informações devem ser utilizadas na construção de banco de dados de teores adequados de nutrientes em diferentes partes da batateira e assim, auxiliar a diagnose nutricional da cultura da batata.
\end{abstract}

Palavras-chave: nutriente, diagnose nutricional, batata

\section{INTRODUCTION}

Potato (Solanum tuberosum L.), a staple food in many countries (McLaughlin et al., 1994), is an important crop in Brazil, cultivated on 170,800 ha (FNP Consultoria \& Comércio, 1998) with increasing commercial importance (Campora, 1994). Brazilian potato tuber yield is low, around $14 \mathrm{t} \mathrm{ha}^{-1}$ (Fontes et al., 1996). Several factors are related to this low yield and the potato nutrition is one of them.

The potato crop receives high levels of fertilizers. Among the nutrients usually used for potato fertilization, $\mathrm{K}$ is of great importance since it is the nutrient taken up in the greatest quantity by the potato plant (Perrenoud, 1993), it is needed for sugar translocation, starch synthesis (Reis Jr \& Fontes, 1996) and to promote high potato tuber yield (Westermann et al., 1994b) of good quality (Westermann et al., 1994a). Although the need of $K$ fertilizer could be high, the elevated input of this nutrient can cause some problems, as undesirable nutrients interactions for example. When $\mathrm{K}^{+}$supply is abundant, "luxury consumption" often occurs, which affects plant composition and interferes with the uptake and physiological availability of $\mathrm{Ca}^{2+}$ and $\mathrm{Mg}^{2+}$ (Marschner, 1995). Interactions between two mineral nutrients are important when the levels of both are near the deficiency range, because increasing the supply of only one mineral nutrient stimulates growth, which in turn can induce a deficiency of the other by the dilution effect (Marschner, 1995). The effects of fertilizer elements on plant composition are interrelated since one fertilizer element may either enhanced or have an antagonistic effect on the absorption of another (Dunn \& Rost, 1948). The high input of $\mathrm{K}$ fertilizer is also unwanted due to the high cost of the fertilizers, which elevates the production cost and reduces the growers' profit. The importance of $\mathrm{K}$ application in the potato crop and problems associated to high fertilizer inputs demand that the fertilizer $\mathrm{K}$ should be used in an efficient way.

Soil analysis and nutritional diagnosis may be adopted to reach the efficient use of fertilizer. Soil tests have been generally used to assess the sufficiency or 
deficiency of various essential plant nutrients (Sharma \& Arora, 1989), but the ability of the plant to grow and acquire nutrients from the soil cannot be predicted safely from the soil analysis alone, since soil analysis does not take in account the climatic factors affecting plant growth (Gupta \& Saxena, 1976). Bergmann (1992) pointed the absence of correlation between the $\mathrm{Mn}$ content on plants and the amounts of $\mathrm{Mn}$ that could be extracted from the soil by various methods as another limitation of soil analysis. Hence, plant tissue analysis could give an efficient mean of monitoring plant nutrient status and also would aid to calibrate fertilizer requirements of potato crops. By monitoring the nutritional status of a crop, potential deficiencies can sometimes be detected early enough for treatments of nutrient disorders during the growing season (Sharma \& Arora, 1989).

Almost every portion of the potato plant has been used to evaluate nutritional status, including: leaflets, petioles, whole leaves, stems, roots, tubers and others dismembered plant parts (Gupta \& Saxena, 1976). The petiole is the commonly selected plant part for use in potato nutritional analysis, although it may not be the most appropriate for all nutrients or in all situations (Walworth \& Muniz, 1993). Petioles are often more sensitive to changes in soil macronutrient concentration, whereas leaf blades are more sensitive to differences in soil micronutrient levels (Dow, 1980).
As nutrient concentration varies with the sampled organ on the plant (Walworth \& Muniz, 1993) and sampling time (Lewis \& Love, 1994), it is necessary to evaluate the nutrient concentration at distinct parts of potato plant and in different sampling time to build data banks of adequate nutrient concentrations. These data banks would help to diagnose the nutritional status of the potato crop with different sampled organ and in diverse sampling times. Several efforts have been made to determine the adequate nutrient concentrations for potato crop in various plant parts and sampling times (Sharma \& Arora, 1989; Walworth \& Muniz, 1993; Reis Jr, 1995; Malavolta et al., 1997; Rocha et al., 1997). TABLE 1 shows the adequate nutrient concentrations described in literature.

Little study about the adequate nutrient concentrations in the different potato organs and diverse sampling time has been reported in Brazil. Such studies are important because this information can be employed to optimize the fertilizer use in potato crops.

The objectives of this study were to determine adequate nutrient concentrations in potato stem, petiole and leaflet in an experiment of increasing levels of $\mathrm{K}$ fertilizer. This investigation was accomplished as a complement of the information of the adequate nutrient concentrations given in Fontes et al. (1996).

TABLE 1- Adequate nutrient concentrations for the potato crop.

\begin{tabular}{|c|c|c|c|c|c|c|c|c|c|c|c|}
\hline Organ & Sampling time & $\mathrm{N}$ & $\mathrm{P}$ & $\mathrm{K}$ & $\mathrm{Ca}$ & $\mathrm{Mg}$ & $\mathrm{S}$ & $\mathrm{Cu}$ & $\mathrm{Mn}$ & $\mathrm{Zn}$ & Author \\
\hline & & $-\cdots$ & - ------- & $\begin{array}{ll}-\cdots- & g\end{array}$ & $\mathrm{~kg}^{-1}--$ & ( & ------ & $-\cdots$ & $\mathrm{mg} \mathrm{kg}^{-1}$ & -------- & \\
\hline Petiole & $\begin{array}{l}\text { tubers half-grown } \\
\text { to maturity }\end{array}$ & $31-50$ & $2.1-5.0$ & $>60$ & $6-25$ & $5-10$ & $2.1-6.0$ & $6-30$ & $21-200$ & $21-705$ & $\begin{array}{l}\text { Walworth \& Muniz } \\
\text { (1993) }\end{array}$ \\
\hline Blades & $\begin{array}{l}\text { tubers half-grown } \\
\text { to maturity }\end{array}$ & 40 & 2.0 & 25 & - & - & - & - & - & - & $\begin{array}{l}\text { Walworth \& Muniz } \\
\text { (1993) }\end{array}$ \\
\hline Leaflet & $\begin{array}{l}50 \text { days after } \\
\text { plant emergence }\end{array}$ & - & 2.42 & - & - & - & - & - & - & - & $\begin{array}{l}\text { Rocha et al. } \\
\text { (1997) }\end{array}$ \\
\hline Petiole & $\begin{array}{l}50 \text { days after } \\
\text { plant emergence }\end{array}$ & - & 1.31 & - & - & - & - & - & - & - & $\begin{array}{l}\text { Rocha et al. } \\
(1997)\end{array}$ \\
\hline Stem & $\begin{array}{l}50 \text { days after } \\
\text { plant emergence }\end{array}$ & - & 1.68 & - & - & - & - & - & - & - & $\begin{array}{l}\text { Rocha et al. } \\
(1997)\end{array}$ \\
\hline Petiole & $\begin{array}{l}35-45 \text { days after } \\
\text { plant emergence }\end{array}$ & 30 & 3.5 & 50 & 20 & 7.5 & 3.5 & $5-8$ & - & - & $\begin{array}{l}\text { Malavolta et al. } \\
(1997)\end{array}$ \\
\hline Petiole & $\begin{array}{l}48 \text { days after } \\
\text { plant emergence }\end{array}$ & - & - & 89 & 6.9 & 6.5 & - & - & - & - & Reis Jr (1995) \\
\hline Petiole & $\begin{array}{l}30 \text { days after } \\
\text { plant emergence }\end{array}$ & - & - & $81-85$ & - & - & - & - & - & - & $\begin{array}{l}\text { Sharma \& Arora } \\
\text { (1989) }\end{array}$ \\
\hline Petiole & $\begin{array}{l}45 \text { days after } \\
\text { plant emergence }\end{array}$ & - & - & $77-85$ & - & - & - & - & - & - & $\begin{array}{l}\text { Sharma \& Arora } \\
\text { (1989) }\end{array}$ \\
\hline Petiole & $\begin{array}{l}60 \text { days after } \\
\text { plant emergence }\end{array}$ & - & - & $71-76$ & - & - & - & - & - & - & $\begin{array}{l}\text { Sharma \& Arora } \\
\text { (1989) }\end{array}$ \\
\hline Leaf & $\begin{array}{l}30 \text { days after } \\
\text { plant emergence }\end{array}$ & - & - & $50-51$ & - & - & - & - & - & - & $\begin{array}{l}\text { Sharma \& Arora } \\
\text { (1989) }\end{array}$ \\
\hline Leaf & $\begin{array}{l}45 \text { days after } \\
\text { plant emergence }\end{array}$ & - & - & $41-45$ & - & - & - & - & - & - & $\begin{array}{l}\text { Sharma \& Arora } \\
\text { (1989) }\end{array}$ \\
\hline Leaf & $\begin{array}{l}60 \text { days after } \\
\text { plant emergence }\end{array}$ & - & - & $37-39$ & - & - & - & - & - & - & $\begin{array}{l}\text { Sharma \& Arora } \\
(1989)\end{array}$ \\
\hline
\end{tabular}




\section{MATERIAL AND METHODS}

A field experiment was conducted on a Clay Tipic Ultisol, with $0-200 \mathrm{~mm}$ soil layer characteristics: coarse sand $=280 \mathrm{~g} \mathrm{~kg}^{-1}$; fine sand $=150 \mathrm{~g} \mathrm{~kg}^{-1}$; silt $=30 \mathrm{~g} \mathrm{~kg}^{-1}$; clay $=540 \mathrm{~g} \mathrm{~kg}^{-1} ; \mathrm{pH}\left(\mathrm{H}_{2} \mathrm{O}\right)=4.7 ; \mathrm{P}=4.16 \mathrm{mg} \mathrm{dm}^{-3} ; \mathrm{K}=$ $1.37 \mathrm{mmol} \mathrm{dm}^{-3} ; \mathrm{Al}^{3+}=9.0 \mathrm{mmol} \mathrm{dm}{ }^{-3} ; \mathrm{Ca}^{2+}=1.7 \mathrm{mmol}^{2}$ $\mathrm{dm}^{-3} ; \mathrm{Mg}^{2+}=0.8 \mathrm{mmol}^{\mathrm{c}} \mathrm{dm}^{-3} ; \mathrm{H}+\mathrm{Al}^{3+}=56.0 \mathrm{mmol}^{\mathrm{dm}} \mathrm{dm}^{-3}$.

The soil was limed as recommended by Comissão de Fertilidade do Solo do Estado de Minas Gerais (1989). Later, $\mathrm{K}_{2} \mathrm{SO}_{4}$ was applied at the rates of: 0,60, 120, 240, 480 and $960 \mathrm{~kg} \mathrm{ha}^{-1}$ of $\mathrm{K}_{2} \mathrm{O}$, in the furrow (100 mm deep). Each plot had four rows with twelve plants each, spaced $0.8 \times 0.3 \mathrm{~m}$. Plants used were only those of the central rows. Before planting, $300 \mathrm{~kg} \mathrm{ha}^{-1}$ of $\left(\mathrm{NH}_{4}\right)_{2} \mathrm{SO}_{4} ; 600 \mathrm{~kg}$ ha ${ }^{-1}$ of $\mathrm{P}_{2} \mathrm{O}_{5} ; 200 \mathrm{~kg} \mathrm{ha}^{-1}$ of $\mathrm{MgSO}_{4} ; 15 \mathrm{~kg}^{-1}$ ha of borax and $15 \mathrm{~kg} \mathrm{ha}^{-1}$ of $\mathrm{ZnSO}_{4}$, were also added to the furrows. Tuber seeds (uniform weight of $80 \pm 5 \mathrm{~g}$ ) were from the "Baraka" cultivar (Solanum tuberosum L.). Ten days after plant emergence (DAE), before the plants were hilled, 700 $\mathrm{kg} \mathrm{ha}^{-1}$ of $\left(\mathrm{NH}_{4}\right)_{2} \mathrm{SO}_{4}$ were applied to the soil. Throughout the growing season, the production system was managed according to the management practices recommended in the region, which included irrigation as needed.

Stem, petioles and leaflets of the youngest fully expanded leaf from two plants/plot were collected at 48 DAE for chemical analysis. Plant samples were dried at $70^{\circ} \mathrm{C}$ for 72 hours and ground to pass through a 20 mesh screen using a stainless steel mill. Plant samples were analyzed for organic-N by the method of Nesler (Jackson, 1958), after the subsamples $(0.1 \mathrm{~g})$ of the dried sampled material were digested with a mixture of concentrated $\mathrm{H}_{2} \mathrm{SO}_{4}(1.5 \mathrm{ml})$ and $\mathrm{H}_{2} \mathrm{O}_{2} 30 \%(1 \mathrm{ml})$ until the digest mixture was clear. Plant samples were analyzed for $P$ colorimetrically by the method of molybidate, $\mathrm{K}$ by flame atomic emission spectroscopy, $\mathrm{Ca}, \mathrm{Mg}, \mathrm{Cu}, \mathrm{Mn}$ and $\mathrm{Zn}$ by atomic absorption spectroscopy and $\mathrm{S}$ turbidimetrically after the subsamples $(0.5 \mathrm{~g})$ of the dried tuber material were digested with a mixture of $65 \%$ nitric $(4 \mathrm{ml})$ and $70 \%$ perchloric acids $(2 \mathrm{ml})$ until the digest mixture was clear. Following natural senescence, the tubers were harvested.

The experiment was set up in randomized blocks design, with four replications. Analysis of variance and regression were used for the evaluation of collected data. The best fitting model was chosen among the linear, quadratic and square root models. To estimate the nutrients concentrations associated to maximum potato yield, the potassium rate associated to maximum potato yield was introduced in the best fitted model, previously established, which relate nutrients concentration to potassium levels.

\section{RESULTS AND DISCUSSION}

Significant response to potassium fertilizer was observed for potato tuber yield, reaching the maximum of $30.5 \mathrm{t} \mathrm{ha}^{-1}$, with $353.4 \mathrm{~kg} \mathrm{ha}^{-1}$ of $\mathrm{K}_{2} \mathrm{O}$ (Fontes et al., 1996).
Stem K concentration $(p<0.05)$ increased with increasing levels of potassium fertilizer, while stem $\mathrm{Ca}$ $(p<0.01), M g(p<0.01), S(p<0.01), C u(p<0.05)$ and $Z n$ $(p<0.05)$ concentration decreased with $K$ fertilizer application (Figures 1,2 and 3). Average stem N, P and $\mathrm{Mn}$ concentration were $22.8 \mathrm{~g} \mathrm{~kg}^{-1}, 1.6 \mathrm{~g} \mathrm{~kg}^{-1}$ and $75.2 \mathrm{mg} \mathrm{kg}^{-1}$, respectively. The increase of stem K concentration is a direct effect of the larger availability of $\mathrm{K}^{+}$in the soil (Reis Jr et al., 1997), as a result of K fertilizer

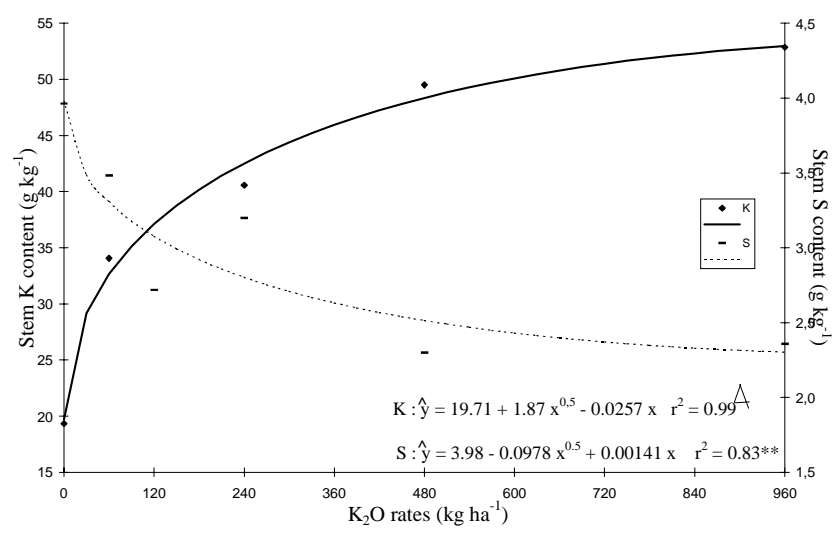

Figure 1 - Effects of various rates of application of $\mathrm{K}_{2} \mathrm{O}$ on potato stem $\mathrm{K}$ and $\mathrm{S}$ concentrations.

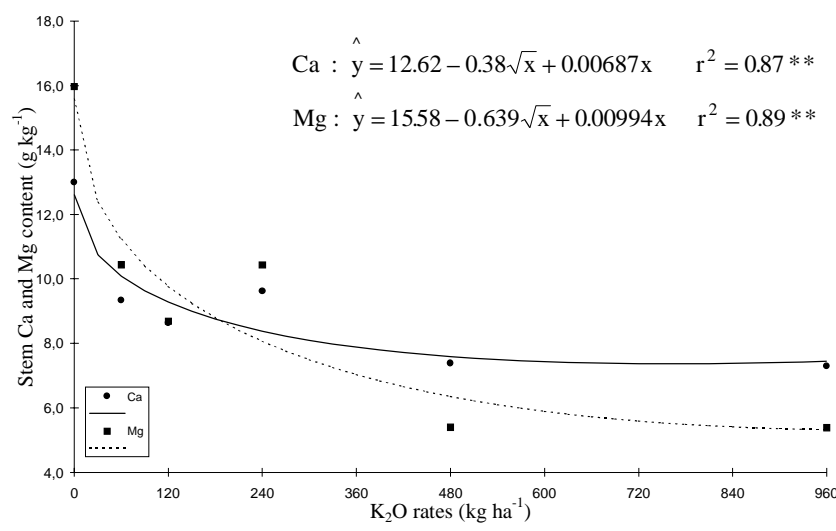

Figure 2 - Effects of various rates of application of $\mathrm{K}_{2} \mathrm{O}$ on potato stem $\mathrm{Ca}$ and $\mathrm{Mg}$ concentrations.

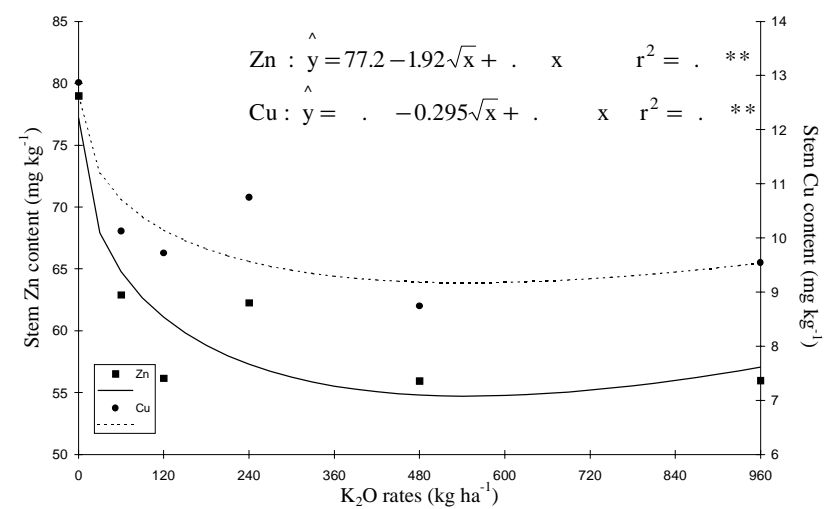

Figure 3 - Effects of various rates of application of $\mathrm{K}_{2} \mathrm{O}$ on potato stem $\mathrm{Zn}$ and $\mathrm{Cu}$ concentrations. 
treatments. The increase of stem dry matter yield with $\mathrm{K}$ fertilizer (Reis Jr \& Fontes, 1999) caused a dilution effect on nutrient concentration, what reduced the stem $\mathrm{S}, \mathrm{Cu}$ and $\mathrm{Zn}$ concentration. Even with the addition of $\mathrm{S}$ to soil (as $\mathrm{K}_{2} \mathrm{SO}_{4}$ ), the $\mathrm{K}$ fertilizer treatments reduced the stem $\mathrm{S}$ concentration; it suggests that the stem is not a good indicator of $S$ nutritional status. The dilution effect associated to ionic antagonism among $\mathrm{K}^{+}, \mathrm{Ca}^{2+}$ and $\mathrm{Mg}^{2+}$ (Glass, 1989; Bergmann, 1992) took to a reduction of stem $\mathrm{Ca}$ and $\mathrm{Mg}$ concentration with increasing levels of $\mathrm{K}$ fertilizer. The adequate concentration of stem $\mathrm{K}(45.8$ $\left.\mathrm{g} \mathrm{kg}^{-1}\right), \mathrm{Ca}\left(7.9 \mathrm{~g} \mathrm{~kg}^{-1}\right), \mathrm{Mg}\left(7.1 \mathrm{~g} \mathrm{~kg}^{-1}\right), \mathrm{S}\left(2.6 \mathrm{~g} \mathrm{~kg}^{-1}\right), \mathrm{Cu}$ $\left(9.3 \mathrm{mg} \mathrm{kg}^{-1}\right)$ and $\mathrm{Zn}\left(55.6 \mathrm{mg} \mathrm{kg}^{-1}\right)$ associated with the maximum tuber yield were determined. The stem $P$ concentration associated with the maximum tuber yield was similar to that suggested by Rocha et al. (1997).

Increasing levels of $\mathrm{K}$ fertilizer increased leaflets $K(p<0.01), S(p<0.01), M n(p<0.05)$ and $Z n(p<0.05)$ concentrations, while decreased $\mathrm{Mg}(\mathrm{p}<0.01)$ concentration (Figures 4 and 5 ). The increase of leaflet $\mathrm{K}$ and $\mathrm{S}$ concentration is a direct effect of the application of $\mathrm{K}_{2} \mathrm{SO}_{4}$ to soil. According to Bergmann (1992), available $\mathrm{Mn}^{2+}$ levels are usually higher in moist soils, and differences in the moisture content of the soil can cause variations in the $\mathrm{Mn}$ contents of plants. Probably, the increasing levels of $\mathrm{K}$ treatments reduced the soil water potential, increasing the soil moisture, what caused a larger Mn uptake and a larger leaflet $\mathrm{Mn}$ concentration consequently. The increase of leaf dry matter yield with $\mathrm{K}$ fertilizer treatments (Reis $\mathrm{Jr}$ \& Fontes, 1999) caused a dilution effect of leaflet $\mathrm{Mg}$ concentration. The ionic antagonism between $\mathrm{K}^{+}$and $\mathrm{Mg}^{+}$ (Glass, 1989) also contributed to leaflet Mg concentration decline with increasing levels of $\mathrm{K}$ fertilizer. The maximum leaflet $\mathrm{K}\left(50.2 \mathrm{~g} \mathrm{~kg}^{-1}\right), \mathrm{Mn}\left(155.2 \mathrm{mg} \mathrm{kg}^{-1}\right)$ and $\mathrm{Zn}(59.6$ $\mathrm{mg} \mathrm{kg}^{-1}$ ) concentration was reached at $687.0,355.8$ and $477.3 \mathrm{~kg} \mathrm{ha}^{-1}$ of $\mathrm{K}_{2} \mathrm{O}$, respectively. The maximum leaflet $\mathrm{Mn}$ concentration occurred nearly the $\mathrm{K}$ level used to obtain the maximum tuber yield. The average leaflets $\mathrm{N}, \mathrm{P}, \mathrm{Ca}$ and $\mathrm{Cu}$ concentrations were $39.9 \mathrm{~g} \mathrm{~kg}^{-1}, 2.1 \mathrm{~g} \mathrm{~kg}^{-1}, 9.1 \mathrm{~g}$ $\mathrm{kg}^{-1}$ and $12.85 \mathrm{mg} \mathrm{kg}^{-1}$, respectively. This leaflet $\mathrm{P}$ concentration was lower than that suggested by Rocha et al. (1997). The adequate leaflet K, Mg, S, Mn and Zn concentration (associated with the maximum tuber yield) were $42.3 \mathrm{~g} \mathrm{~kg}^{-1}, 5.4 \mathrm{~g} \mathrm{~kg}^{-1}, 4.0 \mathrm{~g} \mathrm{~kg}^{-1}, 155.2 \mathrm{mg} \mathrm{kg}^{-1}$ and $59.4 \mathrm{mg} \mathrm{kg}^{-1}$, respectively. Nitrogen and $\mathrm{P}$ leaflet concentration were similar, while $\mathrm{K}$ leaflet concentration was higher than those adequate nutrient concentrations for maximum yield suggested by Walworth \& Muniz (1993).

Potassium fertilizer treatments increased petiole $\mathrm{K}$ concentration, whereas the opposite occurred with petiole $\mathrm{Ca}$ and $\mathrm{Mg}$ concentrations (Fontes et al., 1996). Petiole N $(p<0.01), P(p<0.01)$ and $\mathrm{Cu}(\mathrm{p}<0.05)$ decrease with increasing levels of fertilizer $\mathrm{K}$ (Figure 6 ), while petiole $\mathrm{S}$, $\mathrm{Mn}$ and $\mathrm{Zn}$ average concentration were $3.0 \mathrm{~g} \mathrm{~kg}^{-1}, 117.8$ $\mathrm{mg} \mathrm{kg}^{-1}$ and $26.6 \mathrm{mg} \mathrm{kg}^{-1}$, respectively. The decline of petiole $\mathrm{Ca}$ and $\mathrm{Mg}$ concentration with increasing levels of $\mathrm{K}$ fertilizer is resultant of dilution and ionic antagonism

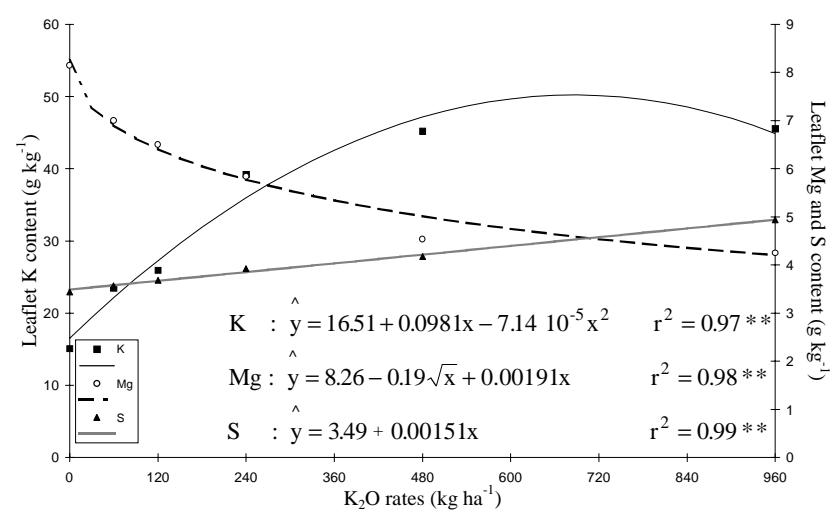

Figure 4 - Effects of various rates of application of $\mathrm{K}_{2} \mathrm{O}$ on potato leaflet $\mathrm{K}, \mathrm{Mg}$ and $\mathrm{S}$ concentrations.

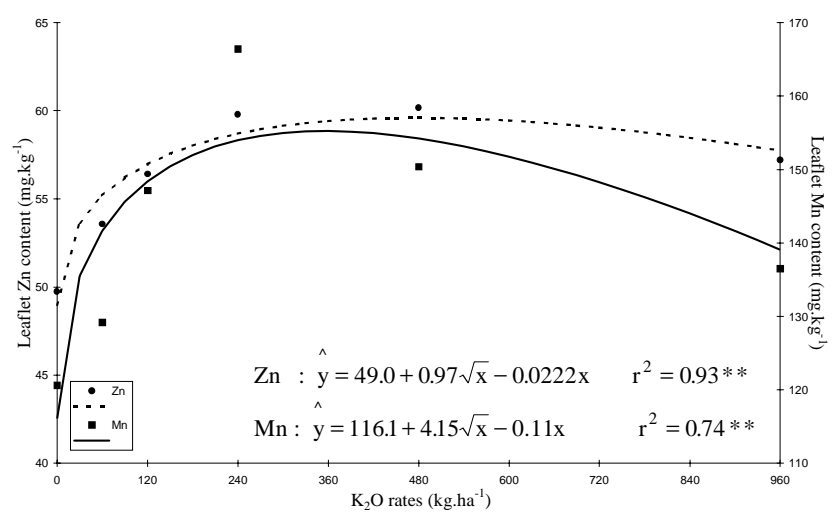

Figure 5 - Effects of various rates of application of $\mathrm{K}_{2} \mathrm{O}$ on potato leaflet $\mathrm{Mn}$ and $\mathrm{Zn}$ concentrations.

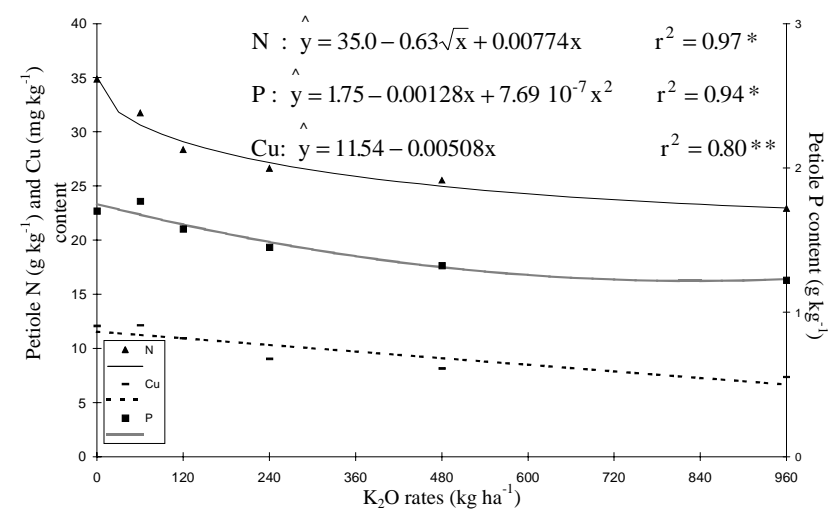

Figure 6 - Effects of various rates of application of $\mathrm{K}_{2} \mathrm{O}$ on potato petiole $\mathrm{N}, \mathrm{P}$ and $\mathrm{Cu}$ concentrations.

among $\mathrm{K}^{+}, \mathrm{Ca}^{2+}$ and $\mathrm{Mg}^{2+}$ effects. Maier (1986) reported an increase in petiole $\mathrm{K}$ concentration and a decrease in petiole $\mathrm{P}$ and $\mathrm{Mg}$ concentration as a result of $\mathrm{K}_{2} \mathrm{SO}_{4}$ application to soil, while Rhue et al. (1986) reported that $\mathrm{K}$ fertilizer application in potato crop increased leaf $\mathrm{K}$ concentration, decreased leaf $\mathrm{Ca}$ and $\mathrm{Mg}$ concentration and did not affect leaf $\mathrm{P}, \mathrm{Cu}, \mathrm{Mn}$ and $\mathrm{Zn}$ concentration. The petiole $\mathrm{N}, \mathrm{P}$ and $\mathrm{Cu}$ concentration associated with the maximum tuber yield were $25.9 \mathrm{~g} \mathrm{~kg}^{-1}, 1.4 \mathrm{~g} \mathrm{~kg}^{-1}$ and 9.7 $\mathrm{mg} \mathrm{kg}^{-1}$, respectively. This petiole $P$ concentration was similar to that suggested by Rocha et al. (1997). In our 
study, petiole nutrient concentration associated to maximum tuber yield are in the range of adequate nutrient concentration for maximum yield suggested by Walworth \& Muniz (1993), except $N$ and $P$, which were lower.

Although Dow (1980) recommend that petioles should be used preferentially to evaluate the macronutrient status, while leaflets should be used preferentially to evaluate the micronutrient status in potato crops, we verified that changes in $\mathrm{Cu}$ status were observed in petioles and not in leaflets while changes in S status were observed in leaflets and not in petioles. Thus, the chemical analysis of petioles and leaflets will give a better diagnosis than when these potato plant parts are used separately to evaluate the nutritional status of potato crops.

As potato crops receives large amounts of fertilizers, growers should pay attention to the effects caused by the high application of these fertilizers. The inadequate nutrient concentration in the different potato plants parts, leading to inadequate nutritional balance, should be avoided because it may lead to a potato yield reduction.

These adequate nutrient concentrations at different potato organs found in this study were for the "Baraka" variety seeded in the fall season, therefore, it will be necessary to verify these findings for others varieties.

\section{CONCLUSION}

Potassium fertilization increased $\mathrm{K}$ concentration and decreased $\mathrm{Mg}$ concentration in potato stem, petiole and leaflet. $\mathrm{N}$ and $\mathrm{P}$ concentrations decreased with increasing levels of $\mathrm{K}$ fertilizer only in the petioles, while $\mathrm{Mn}$ concentration increased by the $\mathrm{K}$ fertilizer treatments only in the leaflets. S and $\mathrm{Zn}$ concentrations decreased with increasing levels of potassium fertilization in the stem, but increased by potassium fertilizer treatments in the leaflets. $\mathrm{Cu}$ concentration decreased with potassium fertilization in the stem and petioles.

We recommend using potato petiole to evaluate the $\mathrm{N}, \mathrm{P}, \mathrm{K}, \mathrm{Ca}, \mathrm{Mg}$ and $\mathrm{Cu}$ status and using potato leaflet to evaluate the $\mathrm{S}, \mathrm{Mn}$ and $\mathrm{Zn}$ status. The stem was not a good indicator of $S$ nutritional status.

The petiole N, $\mathrm{P}$ and $\mathrm{Cu}$ concentrations associated with the maximum tuber yield $\left(30.5 \mathrm{t} \mathrm{ha}^{-1}\right.$, with 353.4 $\mathrm{kg} \mathrm{ha}^{-1}$ of $\mathrm{K}_{2} \mathrm{O}$ ) were $25.9 \mathrm{~g} \mathrm{~kg}^{-1}, 1.4 \mathrm{~g} \mathrm{~kg}^{-1}$ and 9.7 $\mathrm{mg} \mathrm{kg}^{-1}$, respectively, while, the leaflet $\mathrm{S}, \mathrm{Mn}$ and $\mathrm{Zn}$ concentrations associated with the maximum tuber yield were $4.0 \mathrm{~g} \mathrm{~kg}^{-1}, 155.2 \mathrm{mg} \mathrm{kg}^{-1}$ and $59.4 \mathrm{mg} \mathrm{kg}^{-1}$, respectively.

This information should be used to build data banks of adequate nutrient concentration at different portions of potato plant and like this, to aid the nutrient diagnosis in potato crops.

\section{ACKNOWLEDGMENT}

We thank J. Acácio and Cláudia Marinho for their assistance in the laboratory.

\section{REFERENCES}

CAMPORA, P.S. Importância da adubação na qualidade dos produtos agrícolas. São Paulo: Ícone, 1994. 373p.

COMISSÃO DE FERTILIDADE DO SOLO DO ESTADO DE MINAS GERAIS. Recomendações para o uso de corretivos e fertilizantes em Minas Gerais: $4^{a}$ aproximação. Lavras: CFSEMG, 1989. 176p.

DOW, A.I. Critical nutrient ranges in northwest crops. Prosser: Wash State University, 1980. 150p.

DUNN, E.E.; ROST, C.O. Effect of fertilizers on the composition of potatoes grown in the Red River Valley of Minnesota. Soil Science Society Proceedings, v.13, p.374-379, 1948.

FONTES, P.C.R.; REIS JR., R.A.; PEREIRA, P.R.G. Critical potassium concentration and potassium/calcium plus magnesium ratio in potato petioles associated with maximum tuber yields. Journal of Plant Nutrition, v.19, p.657-667, 1996.

FNP CONSULTORIA \& COMÉRCIO. Agrianual 98. São Paulo, 1998. 144p.

GUPTA, A.; SAXENA, M.C. Evaluation of leaf analysis as a guide to nitrogen and phosphorus fertilization of potato (Solanum tuberosum L.). Plant and Soil, v.4, p.597-605, 1976.

JACKSON, M.L. Soil chemical analysis. New Jersey: Prentice Hall, 1958. 498p.

LEWIS, R.J.; LOVE, S.L. Potato genotypes differ in petiole nitratenitrogen concentrations over time. Hortscience, v.29, p.175-179, 1994.

MAIER, N.A. Potassium nutrition of irrigated potatoes in South Australia: II. Effect on chemical composition and the prediction of tuber yield response by plant analysis. Australian Journal of Experimental Agriculture, v.26, p.727-736, 1986.

MARSCHNER, H. Mineral nutrition of higher plants. 2.ed. London: Academic Press, 1995. 889p.

MCLAUGHLIN, M.J.; PALMER, L.T.; TILLER, K.G.; BEECH, T.A.; SMART, M.K. Increased soil salinity causes elevated cadmium concentrations in field grown potato tubers. Journal of Environmental Quality, v.23, p.1013-1018, 1994.

PERRENOUD, S. Potato: fertilizers for yield and quality. Bern: International Potash Institute, 1993. 94p.

REIS JR., R.A. Produção, qualidade de tubérculos e teores de potássio no solo e no pecíolo de batateira em resposta à adubação potássica. Viçosa, 1995. 115p. Tese (Mestrado) Universidade Federal de Viçosa.

REIS JR., R.A.; FONTES, P.C.R. Qualidade de tubérculos da batateira em função de doses de adubação potássica. Horticultura Brasileira, v.14, p.170-174, 1996.

RHUE, R.D.; HENSEL, D.R.; KIDDER, G. Effect of K fertilization on yield and leaf nutrient concentrations of potatoes grown on a sandy soil. American Potato Journal, v.63, p.665-681, 1986.

ROCHA, F.A.T.; FONTES, P.C.R.; FONTES, R.L.F.; REIS, F.P. Critical phosphorus concentrations in potato plant parts at two growth stages. Journal of Plant Nutrition, v.20, p.573-579, 1997.

SHARMA, U.C.; ARORA, B.R. Critical nutrient ranges for potassium in potato leaves and petioles. Journal of Horticultural Science, v.64, p.47-51, 1989.

WALWORTH, J.L.; MUNIZ, J.E. A compendium of tissue nutrient concentrations for field-grown potatoes. American Potato Journal, v.70, p.579-597, 1993.

WESTERMANN, D.T.; JAMES, D.W.; TINDALL, T.A.; HURST, T.R. L. Nitrogen and potassium fertilization of potatoes: sugars and starch. American Potato Journal, v.71, p.433-454, 1994a.

WESTERMANN, D.T.; TINDALL, T.A.; JAMES, D.W.; HURST, T.R.L. Nitrogen and potassium fertilization of potatoes: yield and specific gravity. American Potato Journal, v.71, p.417-432, 1994b.

Received April 20, 1999 